J. Clin. Chem. Clin. Biochem.

Vol. 15, 1977, pp. 225-231

\title{
An Improved Method for the Simultaneous Determination of Individual 17-0xosteroids and of Pregnanediol in Urine by Gas-Liquid Chromatography
}

\author{
By W. R. Külpmann
}

Institut für Klinische Chemie, Medizinische Hochschule Hannover, and $H$. Breuer

\section{Institut für Klinische Biochemie, Universität Bonn}

(Received May 31/November 18, 1976)

Summary: An improved method for the simultaneous gas-chromatographic determination of individual 17-oxosteroids and of pregnanediol in the same sample of urine is described. The method involves the following steps. The urinary sample is chromatographed on Amberlite XAD-2. The fraction containing the steroid conjugates is evaporated; the residue is dissolved in $n$-heptane and the organic phase extracted with water. The steroid glucuronides are hydrolysed by a bacterial $\beta$-glucuronidase; subsequently, the steroid sulphates are solvolysed in ethyl acetate. Free 17-oxosteroids and pregnanediol are separated by two-dimensional thin-layer chromatography. The zone containing the steroids to be investigated is eluted; after evaporation, the residue is treated with $\mathrm{N}$-methyl $\mathrm{N}$-trimethyl silyl trifluoroacetamide. The reaction mixture is injected into a gas chromatograph; the trimethyl silyl ethers of the individual 17-oxosteroids and of pregnanediol are quantitated by measuring the peak heights.

The losses occurring during the working-up procedure are corrected for by measuring the recovery of radioactive dehydroepiandrosterone which is added as glucuronide and as sulphate to the urinary sample. The specificity of the method was established by mass fragmentography.

Eine verbesserte Methode zur gleichzeitigen Bestimmung verschiedener 17-Oxosteroide und von Pregnandiol im Urin mit Hilfe der Gaschromatographie

Zusammenfassung: Es wird eine verbesserte Methode zur gleichzeitigen Bestimmung verschiedener 17-Oxosteroide und von Pregnandiol in derselben Urinprobe mit Hilfe der Gaschromatographie angegeben. Das Verfahren umfaßt folgende Analysen- und Reaktionsschritte. Die Urinprobe wird an Amberlite XAD-2 chromatographiert. Die Fraktion, welche die Steroidkonjugate enthält, wird eingedampft und der Rückstand in $n$-Heptan aufgenommen. Die Steroidkonjugate werden mit Wasser aus der organischen Phase extrahiert. Anschließend werden die Steroidglucuronide mit einer bakteriellen $\beta$-Glucuronidase hydrolysiert und die Steroidsulfate in Essigsäureethylester solvolysiert. Die freien 17-Oxosteroide und Pregnandiol werden durch Dünnschichtchromatographie von begleitenden Verunreinigungen befreit. Die steroidhaltende Zone des Dünnschichtchromatogramms wird eluiert und der Rückstand des Eluats mit N-Methyl-N-trimethylsilyl-trifluoracetamid behandelt. Ein aliquoter Teil der Reaktionsmischung wird in den Gaschromatographen injiziert; die quantitative Bestimmung der Trimethylsilyläther der verschiedenen 17-Oxosteroide und von Pregnandiol erfolgt durch Ausmessung der aufgezeichneten Peakhöhen.

Die Korrektur von Aufarbeitungsverlusten erfölgt durch Ermittlung der Wiederfindung von radioaktivem Dehydroepiandrosteron, das als Glucuronid und Sulfat der Urinprobe zugesetzt wird. Die Spezifität der hier beschriebenen Methode wurde mit Hilfe der Massenfragmentographịe überprüft und bestätigt.

\section{Introduction}

The determination of 17-oxosteroids in urine häs been in widespread use for more than three decades. Of the numerous methods which have been recommended for the measurement of the so-called total 17-oxosteroids, the procedure as modified by Norymberski et al. (1) in 1953 has been the most popular one. However, in certain clinical conditions, such as adreno-genital syndrome, carcinoma of the adrenal cortex and gonadal disorders, it is desirable to obtain information about the urinary excretion of individual 17-oxosteroids. Moreover, it 
seems not unreasonable to assume that, in a number of endocrinological disorders, the determination of individual 17 -oxosteroids may contribute to a better understanding of the underlying pathobiochemical processes. The first method for the fractionation of 17-oxosteroids was published by Dingemanse and her colleagues $(2,3)$ and later improved by Kellie \& Wade (4); the indiviual 17-oxosteroids were separated from each other by chromatography on alumina. These time-consuming methods were succeeded by procedures involving gas chromatography $(5,6,7)$. A critical evaluation of the column chromatography procedures and also of the gas chromatographic methods makes it likely that, in many instances, results obtained do not reflect the correct values for the individual 17-oxosteroids. This is due mainly to two reasons: (1) Hydrolysis of steroid conjugates whether by hot mineral acids or by enzymes, in a native urine sample without prepurification, leads to artifacts or/and incomplete cleavage (8-11). (2) Insufficient purification of the sample prior to gas chromatography may give rise to false results.

The present method has been developed with the aim of avoiding the formation of artifacts by carrying out hydrolysis of the steroid conjugates in prepurified urine. Moreover, a special thin-layer chromatographic technique was devised which yields highly purified samples suitable for the quantitative and specific determination by gas chromatography. The high accuracy of the method is ascertained by using radioactive steroid conjugates as internal standards.

\section{Materials and Equipment}

\section{Steroids}

Pregnanediol (5 $\beta$-pregnane- $3 \alpha, 20 \alpha$-diol), aldosterone $(18,11-$ hemiacetal of $11 \beta, 21$-dihydroxy-3, 20-dioxo-4-pregnen-18-al), androsterone ( $3 \alpha$-hydroxy-5 $\beta$-androstan-17-one), etiocholanolone. ( $3 \alpha$-hydroxy-5 $\alpha$-androstan-17-one), dehydroepiandrosterone

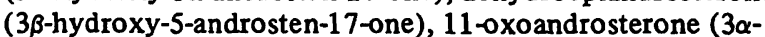
hydroxy-5 $\alpha$-androstane-11, 17-dione), 11-oxoetiocholanolone ( $3 \alpha$-hydroxy-5 $\beta$-androstane-11, 17-dione), $11 \beta$-hydroxyandrosterone $(3 \alpha, 11 \beta$-dihydroxy-5 $\alpha$-androstan-17-one) and $11 \beta$-hydroxy-etiocholanolone ( $3 \alpha, 11 \beta$-dihydroxy- $\beta \beta$-androstan17-one) were obtained from Ikapharm, Ramat-Gan, Israel. The purity of steroids was checked by thin-layer and gas liquid chromatography. Stock solutions (final concentration $1 \mathrm{~g} / \mathrm{l}$ ) were prepared by dissolving steroids in benzene/ethanol (volumes, $90 \mathrm{ml}+10 \mathrm{ml}$ ). The solutions are stable for 6 months when kept at $+4{ }^{\circ} \mathrm{C}$.

\section{Radioactive standards}

$\left[7 \alpha^{-3} \mathrm{H}\right]$ dehydroepiandrosterone $\beta-D$-glucuronide, specific activity $20 \mathrm{Ci} / \mathrm{mmol}$ (New England Nuclear, Boston, Mașs., U.S.A.), $\left[4^{14} \mathrm{C}\right]$ dehydroepiandrosterone sulphate (ammónium salt), specific activity $59.4 \mathrm{mCi} / \mathrm{mmol}$ (New England Nuclear, Boston, Mass., U.S.A.) and $\left[7 \alpha^{-3} \mathrm{H}\right]$ dehydroepiandrosterone sulphate (potassium salt), specific äctivity $290 \mathrm{mCi} / \mathrm{mmol}$ (Radiochemical Centre Amersham, Bucks. U. K., c/o Buchler, Braunschweig, F. R. G.) were used as internal standards. The purity of steroids was checked by thin-layer chromatography, using a radiochro matogram scanner (BF-Vertriebs-GmbH für Meßtechnik, Karlsruhe, F. R. G.).

\section{Chemicals}

Propane-1,2-diol, ethyl acetate, $n$-heptane, toluene, benzene, cyclohexane, chloroform, ethanol and methanol were of A. R. grade. Ethyl acetate, chloroform and methanol were distilled before use. Disodium hydrogen orthophosphate, potassium dihydrogen orthophosphate, sodium hydrogen carbonate, sodium hydroxide, sodium chloride, sulphuric acid were of A. R. grade. Bacterial $\beta$-glucuronidase, type 1 from $E$. coli, was obtained from Sigma, St. Louis, Mo., U.S.A.

The following antibiotics were used: Streptomycin sulphate (Bayer, Leverkusen, F. R. G.): $1.25 \mathrm{~g}$ is dissolved in $1.3 \mathrm{ml}$ distilled sterile water (final concentration $500 \mathrm{~g} / \mathrm{l}$ streptomycin). Nebacetin dry powder (Byk=Gulden, Konstanz, F. R. G.): An amount, corresponding to $50 \mathrm{mg}$ neomycin sulphate and $2500 \mathrm{U}$ Bacitracin, is dissolved in $1.0 \mathrm{ml}$ of $9 \mathrm{~g} / \mathrm{l}$ sodium chloride solution. Penicillin G (Hormon-Chemie, München, F. R. G.): $10^{6} \mathrm{U}(1 \mathrm{MU})$ is dissolved in $2.5 \mathrm{ml}$ distilled sterile water.

Phosphate buffer $(0.45 \mathrm{~mol} / \mathrm{l} ; \mathrm{pH} 7.0)$ was prepared by dissolving $61.24 \mathrm{~g}$ potassium dihydrogen orthophosphate in $1000 \mathrm{ml}$ distilled water and $80.12 \mathrm{~g}$ disodium hydrogen orthophosphate dihydrate in $1000 \mathrm{ml}$ distilled water. $41.3 \mathrm{ml}$ of the potassium salt solution was mixed with $58.7 \mathrm{ml}$ of the sodium salt solution to give $100 \mathrm{ml}$ of phosphate buffer $(0.45$ $\mathrm{mol} / \mathrm{l} ; \mathrm{pH} 7.0)$. Phosphate buffer $(0.075 \mathrm{~mol} / \mathrm{l} ; \mathrm{pH} 7.0)$ was prepared by diluting $1 \mathrm{ml}$ of the phosphate buffer $(0.45 \mathrm{~mol} / \mathrm{l})$ with $5 \mathrm{ml}$ distilled water.

\section{Glassware}

Conical flasks with NS 14.5 standard ground-glass joint (50 ml capacity). Kober test tubes with NS 14.5 standard ground-glass joint ( $40 \mathrm{ml}$ capacity). Conical test tubes with NS 14.5 standard ground-glass joint (capacity $10 \mathrm{ml}$ ). Mikrocaps (capacity $10 \mu \mathrm{l}$ ) (Drummonds Scientific, Broomall, Pa., U.S.A.). Micro syringes (100 $\mu$ l) (ESGE, c/o W. Günther, Analysentechnik, Düsseldorf, F. R. G.). Counting vials (W. Zinsser, Frankfurt/Main, F. R. G.) for liquid scintillation measurements. Assorted pipettes of different cạpacity, Pasteur pipettes, and capillary pipettes (for thin-layer chromatography).

\section{Accessories}

Water bath, centrifuge, shaker, rotavapor, tanks for thin-layer chro matography, UV-lamp.

\section{Column chromatography}

Amberlite XAD-2, coarse, 0.5-1.00 mm diameter (ServaEntwicklungslabor, Heidelberg, F. R. G.) was first washed with water (five times with the threefold volume of the resin) to remove the fines and then washed with methanol (twice with the twofold volume of the resin) to remove impurities. The purified resin was kept under water at room temperature before use. The columns $(20 \times 1.0 \mathrm{~cm}$ internal diameter) were fitted at the bottom with a G-1 sintered glass filter and a capillary outlet. At filling time, the capillary exit was closed by means of a PTFA stop cock and the aqueous suspension of Amberlite $(5 \mathrm{~g})$ poured slowly into the column. The resin was allowed to settle under gravity. The upper end of the filled column was covered with glass wool and glass beads ( $3 \mathrm{~mm}$ diameter). After use, the resin was discarded.

\section{Thin-layer chromatography}

Aluminium sheets (sizes $20 \times 20 \mathrm{~cm}$ ), coated with silica gel $F_{254}$ (thickness of the layer $0.25 \mathrm{~mm}$ ) (Merck, Darmstadt, F. R. G.) were prewashed for $24 \mathrm{~h}$ with chloroform/methanol volumes, $93 \mathrm{ml}+7 \mathrm{ml}$ ), using the technique described by Truter (12).

\section{Gas liquid chromàtography}

Any gas chromatograph with a flame ionisation detector may be used (e. g. Philips-Pye, Philips Elektronik Industrie GmbH, Ham- 
burg, F. R. G.). It contains a siliconised glass column $(2.7 \mathrm{~m}$ $\times 2.4 \mathrm{~mm}$ internal diameter), packed with a mixture of 1 part $3 \%$ OV-210 and 1.8 part 3\% OV-225 on Chromosorb WHP 100 -120 mesh (Supelco, Bellefonte, Pa., U.S.A., c/o Packard Instruments, Frankfurt/Main, F. R. G.). Column temperature: $235^{\circ} \mathrm{C}$. Inlet temperature: $250^{\circ} \mathrm{C}$. Detector temperature: $275^{\circ} \mathrm{C}$. Purged nitrogen was used as carrier gas at a flow rate of $35 \mathrm{ml} / \mathrm{min}$; the flow of hydrogen $(50 \mathrm{ml} / \mathrm{min})$ and air $(250 \mathrm{ml} / \mathrm{min})$ were adjusted for maximal sensitivity.

N-methyl N-trimethyl silyl trifluoracetamide (MSTFA) (Macherey and Nagel, Düren, F. R. G.) was used as silylating agent.

\section{Liquid scintillation counting}

Any liquid scintillation spectrometer (e. g. Packard) may be used. The scintillation fluid contained $4 \mathrm{~g}$ of 2,5-diphenyl-oxazol (PPO) in 11 of dry sulphur-free toluene (Packard Instruments, Frankfurt/ Main, F. R. G.).

\section{Procedure}

\section{Collection and storage of urine samples}

After urine has been collected over a period of $24 \mathrm{~h}$, its volume is measured and then made up with water to $1200 \mathrm{ml}$ or, if more has been excreted, to a larger multiple of $100 \mathrm{ml}$. The diluted urine can be kept indefinitely at $-10^{\circ} \mathrm{C}$ without any detectable change in its concentrations of 17-oxosteroids and pregnanediol.

\section{Chromatography on XAD-2}

$10 \mathrm{ml}$ of urine is used for analysis. The $\mathrm{pH}$ is adjusted to 7.0 with $2 \mathrm{~mol} / 1$ sodium hydroxide and $0.45 \mathrm{~mol} / 1$ phosphate buffer; to each sample, $3,7 \mathrm{kBq}(100 \mathrm{nCi})\left[7 \alpha^{3} \mathrm{H}\right]$ dehydroepiandrosterone glucuronide and $1,85 \mathrm{kBq}(50 \mathrm{nCi})[4-14 \mathrm{C}]$ dehydroepiandrosterone sulphate are added as internal standards. Chromatography is carried out according to Bradlow (13) in the following way:

(a) neutralised urinary sample,

(b) $40 \mathrm{ml}$ water,

(c) $20 \mathrm{ml}$ methanol.

The last fraction contains the conjugates of 17-oxosteroids and pregnanediol, and is collected in conical flasks; after addition of 2 drops of propanediol, the methanol and traces of water are evaporated under vacuum. The residue remains dissolved in propanediol.

\section{Extraction of steroid conjugates}

$5 \mathrm{ml} n$-heptane is added to the propanediol solution; the steroid conjugates are then extrạcted with water $(1 \times 3 \mathrm{ml}, 2 \times 1 \mathrm{ml})$.

\section{Enzymatic hydrolysis}

To the combined aqueous extracts, the following additions are made: $1 \mathrm{ml}$ of $0.45 \mathrm{~mol} / 1$ phosphate buffer, $2500 \mathrm{U} \beta$-glucuronidase, dissolved in $1 \mathrm{ml}$ of $0.075 \mathrm{~mol} / 1$ phosphate buffer, $2.5 \mu 1$ of the penicillin $G$ solution, $10 \mu l$ of the Nebacetin solution, $7 \mu l$ of the streptomycin solution and 2 drops of chloroform The mixture is incubated for $24 \mathrm{~h}$ at $37^{\circ} \mathrm{C}$ in a water bath. The free steroids aree extracted with ethyl acetate $(1 \times 10 \mathrm{ml})$. The extract is transferred to a Kober test tube and the organic phase evaporated under vacuum (Fraction $E_{1}$ ).

\section{Solvolysis}

Solvolysis is carried oüt according to Burstein \& Liebermann (14). The remaining aqueous phase is adjusted to $\mathrm{pH} 1$ by the addition of $1 \mathrm{~mol} / 1$ sulphuric acid; $1.4 \mathrm{~g}$ sodium chloride is added and dissolved by shaking. The mixture is then extracted with ethyl acetate $(3 \times 5 \mathrm{ml})$. The extracts are combined by transfering them separately to the Kober test tube containing fraction $\mathrm{E}_{1}$. This solution is incubated for $24 \mathrm{~h}$ at $37^{\circ} \mathrm{C}$ in a water bath. At the end of the solvolysis, the ethyl acetate phase is washed with sodium hydrogen carbonate solution $(1 \times 1 \mathrm{ml})$. The aqueous solutions are discarded, and the organic phase is evaporated under vacuum.

\section{Thin-layer chromatography}

The residue, containing the liberated steroids from the glucuronide and sulphate fractions, is dissolved in a small volume of chloroform/ methanol (volumes, $90 \mathrm{ml}+10 \mathrm{ml}$ ); the solution is applied to the plate as a $2 \mathrm{~cm}$-line. For the localization of the 17-oxosteroids and pregnanediol, reference steroids with a low $R_{F}$-value (11-oxoetiocholanolone) and with a high $\mathbf{R}_{\mathbf{F}}$-value (androsterone) are also applied. The chromatogram is developed with cyclohexane/ ethyl acetate/methanol (volumes, $10 \mathrm{ml}+90 \mathrm{ml}+5 \mathrm{ml}$ ).

The lane with the reference steroids is cut off and sprayed with sulphuric acid; the steroids are made visible by heating the strips at $120^{\circ} \mathrm{C}$ for $5 \mathrm{~min}$. After localization of the steroid-containing zone, the thin-layer plate is turned around $90^{\circ}$; since aldosterone has a low $R_{F}$-value, as compared with the 17-oxosteroids, and is easily visible under the UV-lamp, it is used as reference steroid for the following thin-layer chromatography steps and applied as a vertical $2 \mathrm{~cm}$-line at a distance of $2 \mathrm{~cm}$. The thin-layer chromatogram (aluminium sheet) is put between two glass plates which are in a horizontal position and cover a glass jar, containing chloroform/methanol (volumes, $93 \mathrm{ml}+7 \mathrm{ml}$ ) (15). About 4/5th of the thin-layer sheet are above the two glass plates and exposed to air. The solvent mixture evaporates as soon as it passes the glass plates. By using this technique, the 17-oxosteroids and pregnanediol fraction as well as aldosterone are concentrated and yield distinct small spots with a diameter less than $1 \mathrm{~mm}$ within $15 \mathrm{~min}$ of development.

The position of aldosterone is checked under UV light. Following this step, the thin-layer chromatogram is developed with chloroform/methanol (volumes, $93 \mathrm{ml}+7 \mathrm{ml}$ ) on the usual way. After the solvent has reached a distance of $8 \mathrm{~cm}$ from the starting line, the zone containing the 17 -oxosteroids and pregnanediol is localised by comparison with authentic androsterone and pregnanediol, using sulphuric acid for visulization. The thin-layer plate is again turned around $90^{\circ}$ and the steroid-containing zone concentrated by developing the chromatogram with chloroform/ methanol (volumes, $93 \mathrm{ml}+7 \mathrm{ml}$ ) in the same way as described above.

The small area containing the 17-oxosteroids and pregnanediol is cut off and put into a glass tube with a sealed-in sintered glass support (G-4) at the bottom. Elution is carried out with $3 \mathrm{ml}$ of chloroform/methanol (volumes, $93 \mathrm{ml}+7 \mathrm{ml}$ ); the eluate is collected into a conical glass tube and evaporated under vacuum.

\section{Meásurement of radioactivity}

The residue is taken up in $100 \mu \mathrm{l}$ benzene/ethanol (volumes, $90 \mathrm{ml}+10 \mathrm{ml}$ ). For the determination of recovery, $10 \mu \mathrm{l}$ of the solution is pipetted with a "mikrocap" into a counting vial, containing $10 \mathrm{ml}$ of scintillation fluid.

\section{Gas liquid chromatography}

The remaining solution $(90 \mu \mathrm{l})$ is evaporated under vacuum. The residue is treated with $90 \mu \mathrm{l}$ MSTFA for $60 \mathrm{~min}$ at $60^{\circ} \mathrm{C}$ in the conical glass tube which is stoppered. For the gas chromatographic determination, $2 \mu$ l of the MSTFA solution is injected into the column.

\section{Calculation of the results}

The amounts of 17-oxosteroids and pregnanediol are calculated from the gas chromatographic tracings by measuring the peak heights. The excretion of the individual 17-oxosteroids and pregnanediol is calculated according to the following formula

$$
\text { Steroid }(\mu \mathrm{mol} / 24 \mathrm{~h})=\frac{\mathrm{m} \times \mathrm{V} \times \mathrm{f}}{\mathrm{R}}
$$

where:

$\mathrm{m}=$ amount of steroid in pmol as determined by gas liquid chromatography

$\mathrm{V}=$ volume of the 24 h-urine in $\mathrm{ml}$ 
$f=$ conversion factor; $5 \times 10^{-4}$, if the volume of the urinary sample is $10 \mathrm{ml}$ and that of the sample injected into the gas chromatographic column is $2 \mu \mathrm{l}$

$\mathrm{R}=\%$ recovery as determined from measurement of radioactivity of the internal standard.

\section{Calibration}

Reference steroids are treated in the same way as the sample to be investigated. Regression lines are calculated on the basis of measurements of three different amounts of each individual steroid. The amounts of steroids, present in the sample quantitated by gas liquid chromatography (m), are calculated by means of the regression lines.

\section{Results}

\section{Criteria of reliability}

\section{Precision}

The precision of the method within the series was determined for each steroid at various concentrations in threefold to sixfold estimations. The standard deviations (S. D.) and coefficient of variation (CV) at the different concentration levels are given in table 1 . The precision from day to day (tab. 2) was calculated from seven determinations of the same urinary sample in four days (4 series).

\section{Accuracy}

Using radioactive dehydroepiandrosterone glucuronide and dehydroepiandrosterone sulphate as internal standards, all values are corrected for $100 \%$ recovery.

Tab. 1. Precision of the method at two concentration ranges and coefficients of variation for the individual steroids.

\begin{tabular}{|c|c|c|c|c|}
\hline Steroid & $\begin{array}{l}\text { Range } \\
{[\mu \mathrm{mol} / 24 \mathrm{~h}]}\end{array}$ & $\mathrm{n}$ & $\begin{array}{l}\text { S. D. } \\
{[\mu \mathrm{mol} / 24 \mathrm{~h}]}\end{array}$ & $\begin{array}{l}\text { Coefficient } \\
\text { of variation } \\
\text { [\%] }\end{array}$ \\
\hline Pregnanediol & $\begin{array}{l}1.13-1.57 \\
1.58-3.91\end{array}$ & $\begin{array}{l}13 \\
19\end{array}$ & $\begin{array}{l}0.07 \\
0.12\end{array}$ & $\begin{array}{l}6.3 \\
4.0\end{array}$ \\
\hline Androsterone & $\begin{array}{l}2.62-5.17 \\
5.18-14.14\end{array}$ & $\begin{array}{r}7 \\
25\end{array}$ & $\begin{array}{l}0.15 \\
0.32\end{array}$ & $\begin{array}{l}5.0 \\
4.0\end{array}$ \\
\hline Etiocholanolone & $\begin{array}{l}2.83-5.17 \\
5.18-19.10\end{array}$ & $\begin{array}{l}12 \\
21\end{array}$ & $\begin{array}{l}0.18 \\
0.51\end{array}$ & $\begin{array}{l}5.1 \\
4.5\end{array}$ \\
\hline $\begin{array}{l}\text { Dehydroepi- } \\
\text { androsterone }\end{array}$ & $\begin{array}{l}0.63-5.21 \\
5.22-7.92\end{array}$ & $\begin{array}{l}16 \\
11\end{array}$ & $\begin{array}{l}0.05 \\
0.25\end{array}$ & $\begin{array}{l}2.9 \\
3.7\end{array}$ \\
\hline $\begin{array}{l}\text { 11-Oxo- } \\
\text { androsterone }\end{array}$ & $\begin{array}{l}0.82-1.64 \\
1.65-3.52\end{array}$ & $\begin{array}{r}7 \\
12\end{array}$ & $\begin{array}{l}0.08 \\
0.26\end{array}$ & $\begin{array}{l}5.8 \\
6.8\end{array}$ \\
\hline $\begin{array}{l}\text { 11-Oxo- } \\
\text { etiocholanolone }\end{array}$ & $\begin{array}{l}0.66-1.64 \\
1.65-2.99\end{array}$ & $\begin{array}{l}12 \\
10\end{array}$ & $\begin{array}{l}0.03 \\
0.12\end{array}$ & $\begin{array}{l}4.3 \\
5.6\end{array}$ \\
\hline $\begin{array}{l}11 \beta \text {-Hydroxy- } \\
\text { androsterone }\end{array}$ & $\begin{array}{l}1.21-1.63 \\
1.64-3.56\end{array}$ & $\begin{array}{r}5 \\
28\end{array}$ & $\begin{array}{l}0.06 \\
0.13\end{array}$ & $\begin{array}{l}5.2 \\
4.9\end{array}$ \\
\hline $\begin{array}{l}11 \beta \text {-Hydroxy- } \\
\text { etiocholanolone }\end{array}$ & $\begin{array}{l}1.01-1.63 \\
1.64-3.56\end{array}$ & $\begin{array}{r}7 \\
17\end{array}$ & $\begin{array}{l}0.05 \\
0.17\end{array}$ & $\begin{array}{r}4.8 \\
.6 .9\end{array}$ \\
\hline
\end{tabular}

Tab. 2. Precision of the method calculated from 7 determinations in 4 days ( 4 series).

\begin{tabular}{|c|c|c|c|}
\hline Steroid & $\begin{array}{l}\text { Mean value } \\
{[\mu \mathrm{mol} / 24 \mathrm{~h}]}\end{array}$ & $\begin{array}{l}\text { S. D. } \\
{[\mu \mathrm{mol} / 24 \mathrm{~h}]}\end{array}$ & $\begin{array}{l}\text { Coeffi- } \\
\text { cient of } \\
\text { variation } \\
{[\%]}\end{array}$ \\
\hline Pregnanediol & 0.33 & 0.03 & 10.3 \\
\hline Androsterone & 1.90 & 0.18 & 9.4 \\
\hline Etiocholanolone & 1.03 & 0.12 & 11.6 \\
\hline Dehydroepiandrosterone & 1.10 & 0.06 & 5.7 \\
\hline 11-Oxoandrosterone & 0.67 & 0.10 & 15.5 \\
\hline 11-Oxoetiocholanolone & 0.89 & 0.05 & 5.7 \\
\hline $11 \beta$-Hydroxyandrosterone & 1.04 & 0.09 & 9.0 \\
\hline $11 \beta$-Hydroxyetiocholanolone & 1.02 & 0.07 & 7.3 \\
\hline
\end{tabular}

These recoveries exclude possible, although practically negligible losses occurring during gas chromatography. The recovery of radioactivity was $94.9 \pm 5.9 \%(n=5)$, when $\left[7 \alpha-{ }^{3} \mathrm{H}\right]$ dehydroepiandrosterone glucuronide was added to the urine sample, $94.8 \pm 5.7 \%(n=4)$ when $\left[4-{ }^{14} \mathrm{C}\right]$ dehydroepiandrosterone sulphate was added, and $95.0 \pm 2.6(n=37)$ when $\left[7 \alpha-{ }^{3} \mathrm{H}\right]$ dehydroepiandrosterone sulphate was added.

\section{Specificity}

The specificity of the method has been investigated by combined gas chromatography-mass spectrometry and by mass fragmentography. The mass spectra, taken from the derivatives of the urinary steroids, were identical with those of the derivatives of the reference standards. The values, measured by mass fragmentography, agreed well with those obtained by gas liquid chromatography. For further details, see $(16,17)$.

\section{Sensitivity}

The sensitivity of the metho is expressed as $3 \times \mathrm{SD}$, obtained by using the SD values determined at concentration levels below $1 \mathrm{mg} / 24 \mathrm{~h}$. The smallest amounts differing significantly from zero are given for the individual steroids in tabble 3 .

Tab. 3. Standard deviations (S. D.) and smallest amounts differing significantly from zero $(3 \times$ S. D.) for pregnanediol and individual 17-oxo-stēroids.

Standard deviations were determined at concentration levels below $1 \mathrm{mg} / 24 \mathrm{~h}$.

\begin{tabular}{|c|c|c|c|}
\hline Steroịd & $\begin{array}{l}\text { Number } \\
\text { of } \\
\text { deter- } \\
\text { mination }\end{array}$ & $\begin{array}{l}\text { S. D. } \\
\text { [jmol/ } \\
24 \mathrm{~h}]\end{array}$ & $\begin{array}{l}\text { Smallest } \\
\text { ạmount differ- } \\
\text { ing significant- } \\
\text { ly from zero } \\
\text { [ } \mu \mathrm{mol} / 24 \mathrm{~h} \text { ] }\end{array}$ \\
\hline Pregnanediol & 23 & 0.07 & 0.21 \\
\hline Androsterone & 7 & 0.15 & 0.45 \\
\hline Etiocholanolone & 3 & 0.09 & 0.27 \\
\hline Dehydroepiandrosterone & 11 & 0.02 & 0.06 \\
\hline 11-Oxoandrosterone & 12 & 0.11 & 0.33 \\
\hline 11-Oxoetiocholanolone & 22 & 0.08 & 0.24 \\
\hline $11 \beta$-Hydroxyandrosterone & 30 & 0.12 & 0.36 \\
\hline $11 \beta$-Hydroxyetiocholanolone & 19 & 0.13 & 0.39 \\
\hline
\end{tabular}




\section{Practicability}

One technician can perform 20 analyses in one working week (5 days). Since the method involves various chromatography, some skill and experience are required. The method has been in use for three years in our laboratory.

\section{Drug interference}

The method described here is less susceptible to drug interference as compared with methods which are based on the determination of 17-oxosteroids by the Zimmermann reaction (cf. 2-4). However, it should be stressed that a number of compounds, particularly synthetic steroids, may directly or indirectly interfere with the determination and thereby falsify the result.

\section{Discussion}

Since no manageable methods are available for the direct measurement of the glucuronides of 17-oxosteroids, these compounds must be hydrolysed, a process which implies certain problems. Thus, the formation of artefacts can only be avoided if enzymes are used for hydrolysis instead of hot mineral acids. To ensure complete enzymatic hydrolysis of steroid conjugates, it is essential to remove all materials, present in the urine sample, which may inhibit the enzymatic reactions. An efficient way for the removal of interfering substances (e. g. glucuronolactone) is the adsorption chromatography of the urine on Amberlite XAD-2 according to Bradlow (13); simultaneously, this step leads to a reduction of the volume of the urine sample which facilitates further handling. Even under the mild conditions of enzymatic hydrolysis, some artefacts may arise, whose formation can be successfully prevented by the addition of antibiotics and traces of chloroform to the urine sample (10). The suggestion of using chromatography on XAD-2 to purify the urine before hydrolysis of the steroid conjugates was made in 1974 (16); since then, the advantages of this procedure have been recognised (18). In contrast to enzyme preparations of different origin, solvolysis leads to a complete cleavage of steroid sulphates as was found with dehydroepiandrosterone sulphate as test compound. Using the well-known method of Burstein \& Lieberman (14), no formation of artefacts during solvolysis was noted; this agrees with reports by other authors $(11,19,20,21)$. The use of internal radioactive standards allows the calculation of $100 \%$ recovery. The rates of recovery are almost identical for both $\left[7 \alpha^{3} \mathrm{H}\right]$ dehydroepiandrosterone glucuronide and $\left[4^{14} \mathrm{C}\right]$ dehydroepiandrosterone sulphate; as these two conjugates are not easily accessible and fairly expensive, it is recommended that $\left[7 \alpha^{-} \cdot{ }^{3} \mathrm{H}\right]$ dehydroepiandrosterone sulphate be used as an alternative internal standard.

The application of a special two-dimensional thin-layer chromatography leads to a concentration of the 17-oxosteroid and pregnanediol fraction which means that only tiny spots have to be eluted from the thin-layer plates. This reduces the amount of nonspecific material which may otherwise interfere with the gas chromatographic determination. The technique of two-dimensional thinlayer chromatography allows the application of the sample as a line, resulting in an improved resolution.

The stationary phase for gas-liquid chromatography (OV 210/OV 225, 1:1.8), as described in the present paper, permits the complete resolution of the individual steroids within $15 \mathrm{~min}$ at a constant temperature. This is a major advantage; compared with the temperature programming of the column oven, isothermal gas-liquid chromatography reduces the time for analysis, increases the reproducibility and facilitates mechanization. Moreover, the phase OV 210/OV 225 is superior to the phase $\mathrm{XE}-60$ because of its higher thermal stability. Typical gas chromatograms are shown in figures $1 \mathrm{a}-1 \mathrm{c}$.

The special feature of the present method is the simultaneous and highly specific determination of seven 17 oxosteroids and pregnanediol. The specificity is based (1) on the chromatography of the urine on Amberlite XAD-2, (2) on the two-dimensional thin-layer chromatography and (3) on the gas chromatography of the MSTFA derivatives of the steroids. For each individual steroid, the specificity as well as the accuracy of its determination were proven by mass fragmentography $(16,17)$.

The normal urinary excretion of 17-oxosteroids varies with age, rising slowly from birth to puberty and then rapidly to a maximum in the mid-twenties (males: 8-26 mg/24 h, mean $15 \mathrm{mg} / 24 \mathrm{~h}$; females: 4-17 mg/ $24 \mathrm{~h}$, mean $10 \mathrm{mg} / 24 \mathrm{~h}$ ) (22). Excretion in both sexes declines during senescence. Although the average for males is higher than that of females of comparable age, the scatter is quite large, and there is considerable overlap of values. The daily excretion of 17-oxosteroids in the young adult varies marginally from day to day. Of the total, $70-85 \%$ is found in the glucuronide fraction, which contains measurable amounts of all compounds except dehydroepiandrosterone. The remainder of the urinary 17 -oxosteroids (15-30\%) appear in the sulphate fraction, of which dehydroepiandrosterone is frequently the major component. Representative values for the individual 17-oxosteroids and pregnanediol are shown in table 4 . The total amount of 17-oxosteroids excreted in urine per $24 \mathrm{~h}$ does not depend on the intake of fluid (23).

The simultaneous determination of individual 17-oxosteroids and pregnanediol is of great value in the diagnosis of the adreno-genital syndrome and in the differentiation of the various forms of enzyme deficiency, underlying this disease. In patients with a $3 \beta$-hydroxysteroid-oxidoreductase deficiency, the excretion of dehydroepiandrosterone is elevated, whereas that of the other 17-oxosteroids and of pregnanediol drops to undetectable values. In $11 \beta$-hydroxylase deficiency, the 


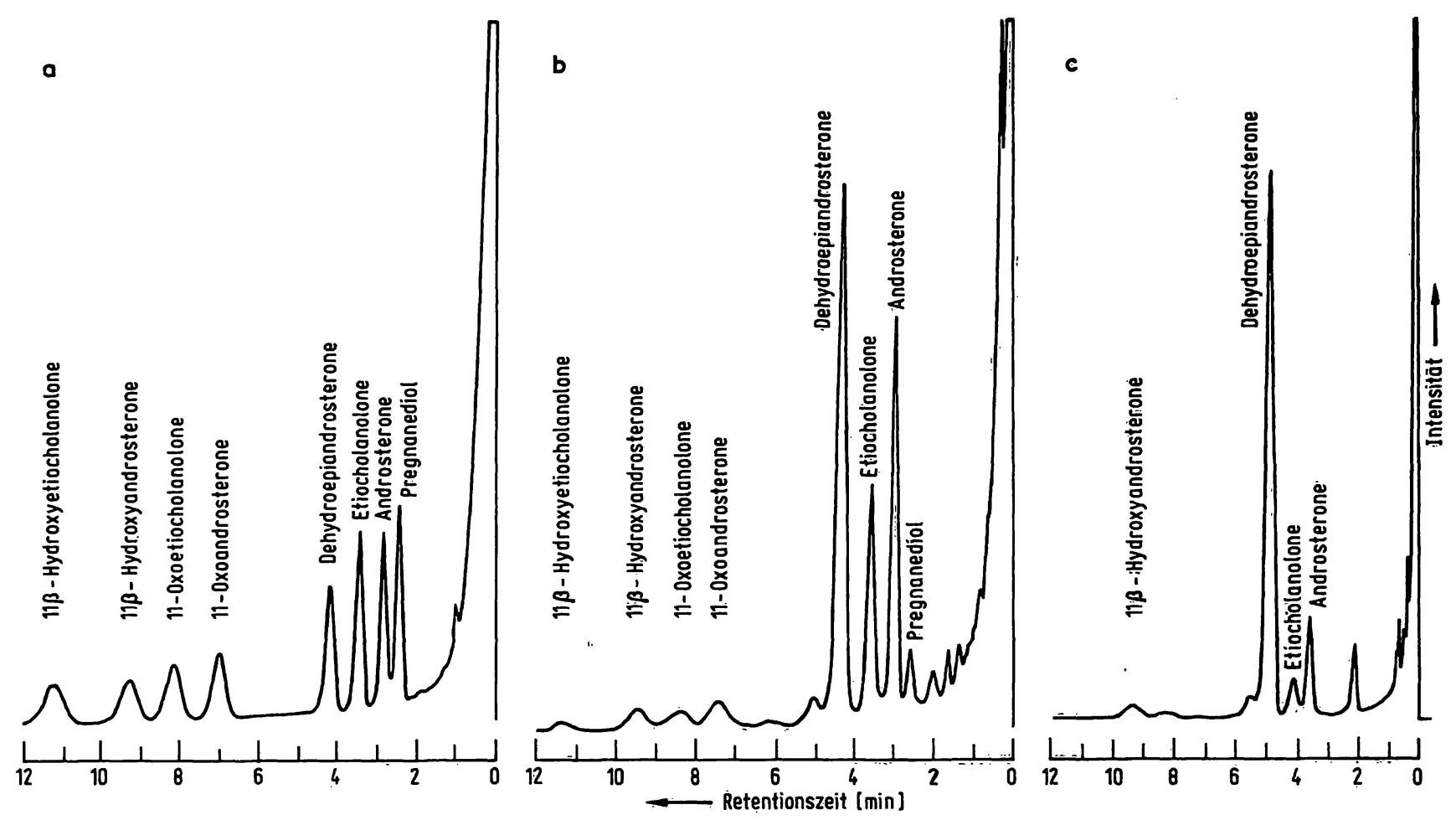

Fig. 1. Gas chromatograms

a) of the trimethylsilylethers of the individual 17-oxosteroids and of pregnanediol. Each peak represents 400 ng of the pure steroid,

b) of the fraction obtained from the urine $(10 \mathrm{ml})$ of a male subject ( 30 yearss) after silylation,

c) of the fraction obtained from the urine $(10 \mathrm{ml})$ of a female subject (11 years) suffering from a blastoma of the adrenal cortex after silylation.

Experimental conditions: $3 \%$ OV-210/3\% OV-225 on Chromosorb WHP 100-120 mesh (1,0:1,8, vol/vol); column temperature: $235^{\circ} \mathrm{C}$, inlet temperature: $250^{\circ} \mathrm{C}$, detector temperature: $275^{\circ} \mathrm{C}$. - The gas chromatograms a and b were recorded at the same sensitivity, $c$ at reduced sensitivity (one tenth of a).

Tab. 4. Urinary excretion of individual 17-oxosteroids and pregnanediol in normal subjects and in a girl (11 years) with an adrenal cortex blastoma before and after operation.

P: Pregnanediol; A: Androsterone; E: Etiocholanolone; D: Dehydroepiandrosterone; OA: 11-Oxoandrosterone; OE: 11-Oxoetiocholanolone; HOA: $11 \beta$-Hydroxyandrosterone; HOE: $11 \beta$-Hydroxyetiocholanolone.

\begin{tabular}{|c|c|c|c|c|c|c|c|c|c|}
\hline \multirow{2}{*}{ Sex } & \multirow{2}{*}{$\begin{array}{l}\text { Age } \\
\text { (Years) }\end{array}$} & \multicolumn{8}{|c|}{ Amounts $[\mu \mathrm{mol} / 24 \mathrm{~h}]$} \\
\hline & & $\mathbf{P}$ & $\mathbf{A}$ & $\mathbf{E}$ & D & OA & $\mathrm{OE}$ & HOA & HOE \\
\hline \multirow{6}{*}{$\begin{array}{l}\text { Female } \\
\text { Male } \\
\text { Male } \\
\text { Female } \\
\text { prae op. } \\
\text { Female } \\
\text { post. op. }\end{array}$} & 23 & 3.38 & 7.76 & 8.62 & 7.92 & 1.94 & 2.99 & 3.20 & 3.40 \\
\hline & 25 & 1.13 & 7.34 & 4.07 & 4.06 & 1.45 & - & 2.42 & - \\
\hline & 40 & 1.25 & 10.41 & 8.52 & 4.34 & 0.82 & 0.66 & 2.26 & 1.14 \\
\hline & & & & & & & & & \\
\hline & 11 & 5.3 & 44.1 & 23.1 & 247.9 & - & - & 23.5 & - \\
\hline & 11 & 1.3 & 2.1 & 1.7 & 2.8 & - & - & 1.3 & - \\
\hline
\end{tabular}

excretion of the 11-oxygenated 17-oxosteroids is markedly decreased and that of the 11-deoxy-17oxosteroids as well as of pregnanediol increased. In 21-hydroxylase deficiency, the excretion of 17-oxosteroids is significantly elevated.

The diagnosis of carcinoma of the adrenal cortex is facilitated by the determination of individual 17-oxosteroids; here, an unusual high excretion of dehydroepiandrosterone is regularly observed.
Furthermore, the differential determination of 17-oxosteroids may be useful in the evaluation of (a) hypothalamic-hypophyseal disorders, such as dystrophia adiposo-genitalis (Fröhlich's syndrome), anorexia nervosa and hypopituitarism, and (b) gonadal disorders, such as Stein-Leventhal syndrome and arrhenoblastoma.

There can be no doubt that the determination of individual 17-oxosteroids will contribute to the elucidation of many endocrinological disorders which are at present poorly understood. 


\section{Literatur}

1. Norymberski, J. K., Stubbs, R. D. \& West, H. F. (1953), Lancet I, 1276-1281.

2. Dingemanse, E., Huis in't Veld, L. G. \& De Laat, B. M. (1946), J. Clin. Endocrinol. 6, 535-548.

3. Dingemanse, E., Huis in't Veld, L. G. \& Hartogh-Katz, S. L. (1952), J. Clin. Endocrinol. 12, 66-85.

4. Kellie, A. E. \& Wade, A. P. (1957), Biochem. J. 66, 196-206.

5. Wotiz, H. H. (1963), Biochim. Biophys. Acta 69, 415-416.

6. Kirschner, M. A. \& Lipsett, M. B. (1963), J. Clin. Endocrinol. $23,255-260$.

7. Curtius, H.Ch. \& Müller, M. (1967), J. Chromatogr. 30, 410-427.

8. Goldzieher, J. W. \& De la Pena, A. (1968), Clin. Chem. (Winston Salem, NC) 14, 1125-1130.

9. Vanek, R. (1.959), Path. Biol. 7, 850-857.

10. Manson, M. E., Nocke-Finck, L., Gustafson, J.-A. \& Shackleton, C. H. L. (1972), Clin. Chim. Acta 38, 45-49.

11. Matthijssen, C. \& Goldzieher, J. W. (1971), Acta Endocrinol. (Copenhagen) 68, 311-333.

12. Truter, E. V. (1964), J. Chromatogr. 14, 57-61.
13. Bradlow, H. L. (1968), Steroids $11,265-272$.

14. Burstein, S. \& Lieberman, S. (1958), J. Biol. Chem. 233, 331-335.

15. Külpmann, W. R., Siekmann, L. \& Breuer, H. (1973), J. Steroid Biochem. 4, 57-61.

16. Külpmann, W. R., Spiegelhalder, B. \& Breuer, H. (1974), this j. $12,252$.

17. Külpmann, W. R., Spiegelhalder, B. \& Breuer, H., in preparation.

18. Graef, V. \& Fuchs, M. (1975), diese Z. 13, 163-167.

19. Rivera, R., Dorfman, R. I. \& Forchielli, E. (1967), Acta Endocrinol. (Copenhagen) 54, 37-50.

20. Holub, W. R. (1971), Clin. Chem. (Winston Salem, NC) 17, 1083-1088.

21. Garmendia, F., Nicolis, G. L. \& Gabrilove, J. L. (1971), Steroids 18, 113-127.

22. Borth, R., Linder, A. \& Riondel, A. (1957), Acta Endocrinol. (Copenhagen) 25, 33-44.

23. Borth, R., Breuer, H. \& Gütgemann, D. (1968), diese Z. 6, 6-11.

Dr. W. R. Külpmann

Institut für Klinische Chemie der Medizinischen Hochschule Karl-Wiechert-Allee 9 D-3000 Hannover 


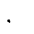

